EDITORIAL

\title{
Digital, Marketing and Online Vídeo Ads: Brand Studies.
}

\author{
Jorge Remondes *
}

\section{INTRODUCTION}

Digital marketing and online advertiding are researched domains that result in a variety of articles with increasingly relevant results for science and organizations.

In this second regular issue of 2021 of the International Journal of Marketing, Communication and New Media (IJMCNM), in three of the four articles, problems of digital marketing, online advertsising and video ads are analyzed.

Digital marketing is one of the most sought-after trends by modern companies, currently allowing innovation and new types of integration between channels (Cabrero, 2016, p.13).

Investing in online advertising in social networks has several advantages (Miranda, 2018, p. 130): brand awareness; knowledge of the consumer profile; high segmentation; generation of leads, traffic, conversions, and remarketing. Miranda (2018) also mentions that in online advertising, namely on YouTube, one should look at the creativity that accompanies the video as well as the segmentation.

\footnotetext{
* Editor-in-chief of IJMCNM, Portugal. E-mail: j.remondes@doc.isvouga.pt
} 
However, as Martínez-Costa; Serrano-Puche; Portillla and Sánchez-Blanco (2019) state, online advertising should adapt its languages and formats for mobile because mobile devices are more used by young adults who are the generation of the future, and also because the use of ad blockers is more frequent on computers than on mobile devices. Feijoo-Fernández; Sádaba-Chalezquer and Bugueño-Ipinza (2020) even highlight that "The new audiences, compared to previous generations, do not reject advertising or brands, but choose the advertising content in which they are genuinely interested" (p.3). Having given this brief introduction, I invite the reader to read all the articles in this issue to learn more about the results achieved in studies developed by researchers from universities and research centres in Brazil, Algeria, Egypt and Saudi Arabia.

\section{STRUCTURE}

In the seventeenth Issue of the IJMCNM, the reader will have online access to four research works about:

1. An Analysis of Tourist's Behavioural Intention in the Digital Era: Using a Modified Model of the Reasoned Action Theory;

2. The Digital Marketing in the Consumer Relations Connection;

3. An Experimental Investigation of the Impact of Different Advertising Formats on Children's Attitudes' Towards Sports Brands;

4. Advertising Review: The Portrayal of Muslim Women Athletes in YouTube Ads.

The papers evaluated by double blind review system belong to authors who have presented the results of their studies that fit in the scientific areas of the IJMCNM; so, they were accepted for publication in this international scientific journal. 


\section{ACKNOLEDGEMENTS}

We would like to thank the authors who have submitted their manuscripts and all the reviewers for their valuable contributions. The scientific importance of the publications in this and previous Issues of the IJMCNM is a strong reason for other authors to submit works for future Regular and Special Issues.

A final thanks to Web of Science ESCI, Qualis CAPES, ERIH Plus, REDIB, RCAPP, MIAR, OAJI, LATINDEX, DRJI, Livre, INDEX COPERNICUS, FREE for the support given to the positioning of IJMCNM in the scientific community.

\section{REFERENCES}

Cabrero, J. D. (2016). Prefácio. In J. Remondes (Coord.), Marketing Digital \& ECommerce (pp.13-14). Psicosoma.

Feijoo-Fernández; Sádaba-Chalezquer e Bugueño-Ipinza (2020). Anuncios entre vídeos, juegos y fotos. Impacto publicitário que recibe el menor a través del teléfono móvil. Profesional de la información, v. 29, n. 6, e290630.

Martínez-Costa, M-P; Serrano-Puche, J.; Portillla, I., \& Sánchez-Blanco, C. (2019). La interacción de los jóvenes adultos con las noticias y la publicidade online. Comunicar, $\mathrm{n}^{\mathrm{o}} 59$, v. XXVII, pp. 19-28.

Miranda, M. (2018). YouTube, Facebook e Instagram Ads. In J. Remondes (Coord.), Marketing Digital \& E-Commerce: Gestão de Conteúdos e Publicidade Online (pp.125164). Psicosoma.

\section{How to cite this article:}

Remondes, J. (2021). Digital, Marketing and Online Vídeo Ads: Brand Studies, International Journal of Marketing, Communication and New Media, Vol. 9, N 17, 1-3. 